\title{
The effect of some chemicals on the color properties of Beech (Fagus Orientalis L.) wood
}

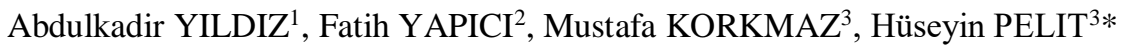 \\ ${ }^{1}$ Dicle University, Vocational School of Technical Sciences, Diyarbakır, TURKEY \\ ${ }^{2}$ Samsun Ondokuz Mayıs University, Faculty of Engineering, Samsun, TURKEY \\ ${ }^{3}$ Düzce University, Technology Faculty, Düzce, TURKEY \\ *Corresponding author: huseyinpelit@duzce.edu.tr
}

Received Date: 06.01.2017

Accepted Date: 24.08 .2017

\begin{abstract}
Aim of study: Wood material has a unique color in the natural condition. The wood colorization process is necessary to provide a tonality in the wood materials used in interior design and decoration and to obtain different colors. One of the most important steps of the coloring or bleaching process is selecting appropriate chemical for wood type. The aim of this study was to determine the effect of hydrogen peroxide, ammonia, sodium silicate and acetic acid applied periodically three times on the color changes of radial and tangent sections of beech (Fagus Orientalis L.) samples.

Area of study: This study was conducted at Karabük University and Düzce University, in Turkey.

Material and Methods: The color values of the samples were measured according to the CIEL*a*b* color system.

Main results: As a result, the effect of cutting direction, chemical type, and application repeat on changes in the color values of beech samples was found significant.

Research highlights: The maximum color change in the beech samples was determined in the radial section as cutting direction, in the application of the sodium silicate as the chemical type and it was also obtained in the third repeat as the number of applications.
\end{abstract}

Keywords: Beech wood, Chemicals, Color changing

\section{Bazı kimyasalların Kayın (Fagus Orientalis L.) odununun renk}

\section{özellikleri üzerine etkisi}

Özet

Çalışmanın amacı: Doğal haldeki ağaç malzemenin kendine özgü bir rengi vardır. İç mimari ve dekorasyonda kullanılan ağaç malzemelerde renk uyumunu sağlamak veya farklı görüntüler elde etmek için çoğu zaman renklendirme ve renk açma işlemlerine ihtiyaç vardır. Renklendirme veya renk açma işleminin en önemli basamaklarından birisi ağaç türüne uygun kimyasalın seçilmesidir. Bu araştırmanın amac1, kayın (Fagus Orientalis L.) odunundan radyal ve teğet kesitte hazırlanmış örneklere belirli aralıklarla üçer kez uygulanan hidrojen peroksit, amonyak, sodyum silikat ve asetik asit kimyasallarının örneklerde meydana getirdiği renk değişimini belirlemek içindir.

Çalışma alanı: Bu çalışma Karabük Üniversitesi ve Düzce Üniversitesinde gerçekleştirilmiştir.

Materyal ve Yöntem: Örneklerin renk değerleri CIEL*a*b* renk sistemine göre ölçülmüştür.

Sonuçlar: Araştırma sonuçlarına göre; kayın örneklerin renk değerlerindeki değişimde kesiş yönü, kimyasal çeşidi ve uygulanma tekrarı önemli bulunmuştur.

Araştırma vurguları: Örneklerdeki en fazla renk değişiminin; kesiş yönü olarak radyal kesitte, kimyasal çeşidi olarak sodyum silikat uygulamasında ve uygulama sayısında ise üçüncü tekrarda olduğu belirlenmiştir.

Anahtar kelimeler: Kayın odunu, Kimyasallar, Renk değişimi 


\section{Introduction}

Color is one of the most important properties of wood regarding aesthetic and decorative aspects. The color of the material may differ from one species to another. Similarly, not only may it differ in same species, but it may also differ in parts of the same wood prepared from a lumber. The color of wood material can be affect some properties of wood such as texture, density, the amount of moisture, the quantity of color pigments in the cell membrane and so forth (Sönmez, 2005; Budakçı et al., 2012).

Color is as important as the size and form in the wooden furniture. The color of the wooden furniture is expected to be compatible with the interior design components such as wall, ceiling, floor, carpets, curtains, etc. While the color of the wood in its natural state often does not meet such a need. Before finishing process, desired color harmony can be achieved with surface operations such as bleaching and coloring on the surfaces (Çakıcıer, 1996; Özçifçi et al., 1999; Örs and Atar, 2001). Also bleaching process is performed in the industrial applications such as eliminate the color differences during furniture production or prevent to color changes that may occur after production of furniture (Sönmez, 2005).

Bleaching is the process of lightening of wood surface color with a appropriate solution. When natural wood material exposed to external impacts, especially, a darkening in color occurs. Bleaching chemicals are reactives that affect the secondary components of wood. These chemicals make colors lighter by affecting the secondary components of wood instead of destroying the color. (Wagner and Kiclighter, 1986; Budakçı and Atar, 2001). This process significantly effects some wood surface properties such as hardness, color, gloss, roughness, adhesion, scratch (Özdemir and Hızıroğlu, 2007; Budakçı and Karamanoğlu, 2014; Özdemir et al., 2015).

There are many studies in the literature on the color properties of wood materials exposed to bleaching solutions or impregnation, especially in the tree species which are frequently used in the woodworking sector. The color of wood material exposed to outdoor conditions get darker and the color properties of each wood species is affected in different amounts due to chemicals changes on the microstructure (Feirer, 1984). It was stated that the glossiness value of wood material exposed to outdoor conditions decreased and the bleaching process with chemicals decreased this effect of outdoor conditions (Budakçı and Atar, 2001). According to a study performed with 11 different chemical bleach solutions on the 5 different wood, each solution effects wood and its properties differently and each solutions is not suitable with each wood species (Herstedt and Herstedt, 2017).

The coloring process is made to change the wavelength of reflected light from the surface of the wood by forming new compounds on the wood texture using chemical methods or impregnating color pigments into wood (Sönmez, 2005). In the natural state and without any protective layer, wood material is destroyed in a shot time when exposed to external effect. Bleaching chemicals cannot protect wood material against external effects because they does not form a protective layer. For this reason, bleached wood surfaces must be covered with a protective layer (Sönmez, 1989).

The goal of this study, was to determine the effect of hydrogen peroxide, ammonia, sodium silicate and acetic acid applied periodically three times on the color properties $\left(\mathrm{L}^{*}, \mathrm{a}^{*}, \mathrm{~b}^{*}\right.$ and $\left.\Delta \mathrm{E}^{*}\right)$ of radial and tangent sections of beech (Fagus Orientalis L.) wood samples.

\section{Material and Method Wood material}

Eastern beech (Fagus Orientalis L.), which is often preferred in furniture production, was used in the study. Attention was paid to ensure that no rot, knot, crack, color, or density differences were present in the beech samples (TS 2470 1976). Beech samples was cut with the dimensions of $190 \times 140 \times 15 \mathrm{~mm}$ from both radial and tangential section. Surfaces of the samples were sanded with 220 grit sandpaper and then samples were stored in climate room 
(RH $65 \pm 3 \%$ and $20 \pm 2{ }^{\circ} \mathrm{C}$ ) for 3 weeks (TS 2471 1976).

\section{Chemicals}

In the study, $50 \%$ hydrogen peroxide $\left(\mathrm{H}_{2} \mathrm{O}_{2}\right), 80 \%$ acetic acid $\left(\mathrm{CH}_{3} \mathrm{COOH}\right)$, ammonia $\left(\mathrm{NH}_{3}\right), 40^{\circ}-42^{\circ}$ sodium sillicate $\left(\mathrm{Na}_{2} \mathrm{SiO}_{3}\right)$ solutions was preferred as chemicals because these were widely used in bleaching process of wood.

Hydrogen peroxide, acetic acid and ammonia solutions were applied to sample surfaces for thrice with 48 hours intervals. Because sodium silicate takes longer to dry out, it was applied with 72 hours intervals for thrice. Chemicals were applied to wood surface with a colorless (white) cloth and chemical residues removed from the surface with distilled water after waiting 10 minutes.

\section{Determination of color}

Before and after the implementation of chemicals, color values of all samples were determined with Superchroma spectrophotometer (Braive Instruments) according to ASTM D2244 (2015). The differences in colors and their locations are determined according to the $\mathrm{L}^{*}, \mathrm{a}^{*}$, and $\mathrm{b}^{*}$ color coordinates in the CIEL*a*b* color scheme (Fig. 1). In this scheme, L* (lightness) is located on the black-white axis ( $L^{*}=0$ for black, $L^{*}=100$ for white), $a^{*}$ on the red-green axis (positive values for red and negative values for green), and $b^{*}$ for the yellow-blue axis (positive values for yellow and negative values for blue) (Oliver et al., 1992; McGuire, 1992; Mononen et al., 2002). The color red $(+a)$ and the color yellow $(+b)$ was independently investigated in order to determine which color tone was affected in each color during change and in addition, the total change in color $\left(\Delta \mathrm{E}^{*}\right)$ was calculated using the following Eq.1:

$$
\Delta E^{*}=\sqrt{\left(\Delta L^{*}\right)^{2}+\left(\Delta a^{*}\right)^{2}+\left(\Delta b^{*}\right)^{2}}
$$

where $\Delta \mathrm{L}^{*}\left(\mathrm{~L}^{*}{ }_{\text {treated }}-\mathrm{L}^{*}\right.$ control $)$ is the color change of black-white, $\Delta \mathrm{a}^{*}\left(\mathrm{a}^{*}\right.$ treated $-\mathrm{a}^{*}$ control $)$ is the color change of red-green, $\Delta b^{*}\left(b^{*}\right.$ treated $-b^{*}$ control) is the color change of yellow-blue. The low $\Delta \mathrm{E}^{*}$ values obtained from the calculations would indicate very low or no change in color (Söğütlü and Sönmez, 2006).

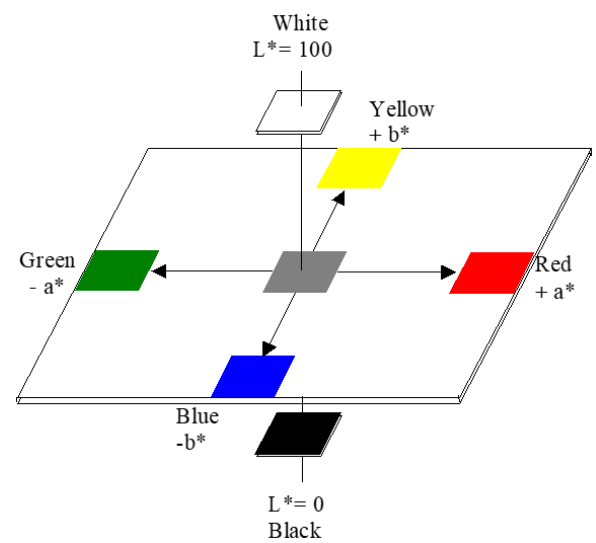

Figure 1. CIEL*a*b* color scheme

\section{Statistical analysis}

The MSTAT-C package program was used for statistical evaluations. Multiple analysis of variance (ANOVA) tests were performed to determine the effect of different chemicals applied at certain intervals on the color parameters $\left(L^{*}, a^{*}, b^{*}\right.$ and $\left.\Delta E^{*}\right)$ of the beech wood samples (0.05 significance level). Significant differences between the groups were compared using the Duncan test.

\section{Results and Discussion}

The color changes on radial and tangent section of samples caused by different chemicals applied thrice at specific intervals were shown in Table 1.

Table 1 . The average $\mathrm{L}^{*}, \mathrm{a} *, \mathrm{~b} *$ and $\Delta \mathrm{E} *$ values of Eastern beech samples before and after chemical application $(n=10)$

\begin{tabular}{|c|c|c|c|c|c|c|c|c|c|}
\hline \multirow{3}{*}{$\begin{array}{l}\text { Chemical } \\
\text { type }\end{array}$} & \multirow{3}{*}{$\begin{array}{l}\text { Application } \\
\text { repeat }\end{array}$} & \multicolumn{8}{|c|}{ Cutting direction } \\
\hline & & \multicolumn{4}{|c|}{ Tangential section } & \multicolumn{4}{|c|}{ Radial sections } \\
\hline & & $\mathrm{L}^{*}$ & $\mathrm{a}^{*}$ & $\mathrm{~b}^{*}$ & $\Delta \mathrm{E}^{*}$ & $\begin{array}{l}* \\
L^{*}\end{array}$ & $\mathrm{a}^{*}$ & $\mathrm{~b}^{*}$ & $\Delta \mathrm{E}^{*}$ \\
\hline \multirow[t]{2}{*}{$\begin{array}{l}\text { Acetic } \\
\text { acid }\end{array}$} & Control & $\begin{array}{l}70.09 \\
(3.93)\end{array}$ & $\begin{array}{l}4.02 \\
(0.69)\end{array}$ & $\begin{array}{l}22.09 \\
(1.19)\end{array}$ & - & $\begin{array}{l}74.24 \\
(1.02)\end{array}$ & $\begin{array}{l}3.33 \\
(0.61)\end{array}$ & $\begin{array}{l}20.40 \\
(0.89)\end{array}$ & - \\
\hline & 1 times & $\begin{array}{l}72.05 \\
(3.18)\end{array}$ & $\begin{array}{l}3.34 \\
(0.54)\end{array}$ & $\begin{array}{l}22.63 \\
(0.92)\end{array}$ & $\begin{array}{l}2.62 \\
(1.77)\end{array}$ & $\begin{array}{l}74.58 \\
(1.12)\end{array}$ & $\begin{array}{l}3.30 \\
(0.70)\end{array}$ & $\begin{array}{l}22.13 \\
(1.31)\end{array}$ & $\begin{array}{l}2.13 \\
(1.29)\end{array}$ \\
\hline
\end{tabular}


Table 1. (continued)

\begin{tabular}{|c|c|c|c|c|c|c|c|c|c|}
\hline & 2 times & $\begin{array}{l}71.12 \\
(2.89)\end{array}$ & $\begin{array}{l}3.26 \\
(0.60)\end{array}$ & $\begin{array}{l}22.15 \\
(1.14)\end{array}$ & $\begin{array}{l}2.28 \\
(1.20)\end{array}$ & $\begin{array}{l}73.16 \\
(1.54)\end{array}$ & $\begin{array}{l}3.90 \\
(1.01)\end{array}$ & $\begin{array}{l}22.91 \\
(1.26)\end{array}$ & $\begin{array}{l}2.97 \\
(2.01)\end{array}$ \\
\hline & 3 times & 69.77 & 7.25 & 23.52 & 4.24 & 73.20 & 6.53 & 22.14 & 4.16 \\
\hline & & (2.64) & $(0.59)$ & (1.37) & (1.16) & (1.84) & $(0.70)$ & (0.91) & $(0.85)$ \\
\hline \multirow[t]{8}{*}{ Ammonia } & Control & 69.27 & 3.97 & 19.30 & - & 73.97 & 4.75 & 21.44 & - \\
\hline & & (2.72) & (0.88) & (1.47) & & (1.83) & & (1.13) & \\
\hline & 1 times & 59.18 & 4.54 & 17.59 & 10.32 & 60.13 & 6.80 & 18.71 & 14.48 \\
\hline & & (3.67) & (1.03) & (1.39) & (3.56) & (2.93) & (1.20) & (1.07) & (3.11) \\
\hline & 2 times & 58.14 & 7.58 & 21.69 & 12.09 & 55.44 & 11.60 & 22.51 & 19.85 \\
\hline & & (3.13) & (1.19) & (1.43) & (3.60) & (1.21) & (1.27) & (0.72) & (2.24) \\
\hline & 3 times & 59.44 & 7.11 & 21.83 & 10.80 & 56.13 & 10.50 & 22.76 & 18.86 \\
\hline & & (3.09) & (1.08) & (1.40) & (3.58) & $(2.50)$ & (0.65) & (0.49) & (3.31) \\
\hline \multirow{8}{*}{$\begin{array}{l}\text { Hydrogen } \\
\text { peroxide }\end{array}$} & Control & 66.92 & 4.72 & 18.71 & - & 74.59 & 4.26 & 20.05 & - \\
\hline & & $(4.25)$ & $(1.32)$ & (2.44) & & (1.77) & $(0.85)$ & (1.34) & \\
\hline & 1 times & 78.40 & 1.94 & 21.49 & 12.40 & 82.45 & -0.13 & 17.44 & 9.53 \\
\hline & & $(2.81)$ & (1.67) & (1.07) & (3.12) & (2.03) & (1.86) & (2.42) & (2.29) \\
\hline & 2 times & 84.74 & -2.52 & 16.74 & 19.74 & 87.05 & -3.70 & 13.83 & 16.08 \\
\hline & & (3.32) & $(2.31)$ & (2.49) & (2.82) & (1.36) & $(0.89)$ & $(1.20)$ & (1.90) \\
\hline & 3 times & 87.27 & -0.05 & 17.57 & 21.21 & 89.10 & -0.68 & 14.95 & 16.26 \\
\hline & & (1.90) & $(1.30)$ & (1.33) & (2.62) & $(0.90)$ & $(0.47)$ & (1.24) & (1.99) \\
\hline \multirow{8}{*}{$\begin{array}{l}\text { Sodium } \\
\text { silicate }\end{array}$} & Control & 70.70 & 4.12 & 18.80 & - & 74.38 & 3.91 & 19.50 & - \\
\hline & & $(2.27)$ & $(1.22)$ & (1.55) & & (1.01) & (0.99) & (0.74) & \\
\hline & 1 times & 57.17 & 8.57 & 28.80 & 17.53 & 54.33 & 9.24 & 28.25 & 22.67 \\
\hline & & $(2.72)$ & (1.46) & (1.84) & (2.88) & (1.89) & (0.63) & (1.72) & (1.26) \\
\hline & 2 times & 58.18 & 10.44 & 29.79 & 17.86 & 60.86 & 8.49 & 23.72 & 15.40 \\
\hline & & (2.83) & $(1.28)$ & (1.45) & (1.30) & (3.17) & (1.73) & (4.10) & (3.97) \\
\hline & 3 times & 57.02 & 10.41 & 31.25 & 19.58 & 59.84 & 8.66 & 26.64 & 17.16 \\
\hline & & (3.02) & (1.34) & (1.46) & $(2.65)$ & (2.42) & (1.73) & (3.74) & $(4.03)$ \\
\hline
\end{tabular}

Values in parenthesis are standard deviations

Applied chemicals and number of repetition of these chemicals changed of $\mathrm{L}^{*}$, $a^{*}, b^{*}$ color values of beech samples. $L^{*}, a^{*}$, $\mathrm{b}^{*}$ and $\Delta \mathrm{E}^{*}$ values were separately analyzed for determining of the color change amount and factors which are effective on the color changes of samples.

\section{Color lightness value $\left(\mathrm{L}^{*}\right)$}

Analysis of variance (ANOVA) results of color lightness $\left(\mathrm{L}^{*}\right)$ values of samples applied with acetic acid, ammonia, hydrogen peroxide and sodium silicate at different repetition numbers were shown in Table 2 .

Table 2. ANOVA results of the $\mathrm{L}^{*}$ values of beech samples

\begin{tabular}{lccccc}
\hline Factors & $\begin{array}{c}\text { Degrees of } \\
\text { freedom }\end{array}$ & $\begin{array}{c}\text { Sum of } \\
\text { squares }\end{array}$ & $\begin{array}{c}\text { Mean } \\
\text { square }\end{array}$ & F-value & $\begin{array}{c}\text { Level of } \\
\text { significance } \\
(p \leq 0.05)\end{array}$ \\
\hline Cutting direction (A) & 1 & 360.464 & 360.464 & 55.0875 & 0.0000 \\
Chemical type (B) & 3 & 21953.876 & 7317.959 & 1118.3581 & 0.0000 \\
Interaction (AB) & 3 & 188.136 & 62.712 & 9.5839 & 0.0000 \\
Application repeat (C) & 3 & 855.219 & 285.073 & 43.5659 & 0.0000 \\
\hline
\end{tabular}


Table 2. (continued)

\begin{tabular}{|c|c|c|c|c|c|}
\hline Interaction (AC) & 3 & 228.684 & 76.228 & 11.6494 & 0.0000 \\
\hline Interaction (BC) & 9 & 8992.765 & 999.196 & 152.7009 & 0.0000 \\
\hline Interaction (ABC) & 9 & 228.713 & 25.413 & 3.8836 & 0.0001 \\
\hline Error & 288 & 1884.523 & 6.543 & & \\
\hline Total & 319 & 34692.379 & & & \\
\hline
\end{tabular}

According to ANOVA results; there was a significant interaction between cutting direction, chemical type and application repetition number factors and these factors was also significant on the changes of the $\mathrm{L}^{*}$ values of beech samples $(p \leq 0.05)$.
Duncan test results of the comparison in the level of cutting direction, chemical type and application repetition number were given in the Table 3.

Table 3. Duncan test results of the $\mathrm{L}^{*}$ values in the level of comparison of cutting direction, chemical type and application repetition number

\begin{tabular}{|c|c|c|c|}
\hline Cutting direction & Mean & $H G$ & \multirow{3}{*}{$\begin{array}{c}L S D \\
\pm 0.5629\end{array}$} \\
\hline Tangential section & 68.09 & b & \\
\hline Radial sections & 70.21 & $\mathrm{a}$ & \\
\hline Chemical type & Mean & $H G$ & \multirow{5}{*}{$\begin{aligned} & L S D \\
\pm & 0.7960\end{aligned}$} \\
\hline Ammonia & 61.46 & $\mathrm{c}$ & \\
\hline Sodium silicate & 61.56 & $\mathrm{c}$ & \\
\hline Acetic acid & 72.28 & $\mathrm{~b}$ & \\
\hline Hydrogen peroxide & 81.31 & $\mathrm{a}$ & \\
\hline Application repeat & Mean & $H G$ & \multirow{5}{*}{$\begin{array}{c}L S D \\
\pm 0.7960\end{array}$} \\
\hline 1 times & 67.29 & $\mathrm{c}$ & \\
\hline 2 times & 68.59 & $\mathrm{~b}$ & \\
\hline 3 times & 68.97 & b & \\
\hline Control & 71.77 & $\mathrm{a}$ & \\
\hline
\end{tabular}

HG: Homogeneous group 
According to table 3 ; the $\mathrm{L}^{*}$ value was found higher (70.21) on the radial section when compared with the tangential section. It could be said that the type of the rays of beech samples were effective on the results. Due to the anatomical structure of the beech wood, rays is found in the form of dots on the tangential section and in the form of strands on the radial section (Örs and Keskin, 2008). In terms of chemical type, the highest $\mathrm{L}^{*}$ value found on the samples applied hydrogen peroxide (81.31), the lowest value found on the both samples applied ammonia (61.46) and sodium silicate (61.56) which are statistically insignificant. Ammonia and sodium silicate chemicals, which are alkaline, caused a reduction in the $\mathrm{L}^{*}$ value of beech samples (Table 1). It was reported that alkaline chemicals causes darkening of color conditions of wood materials and also

\begin{tabular}{|c|c|c|c|c|c|}
\hline Factors & $\begin{array}{l}\text { Degrees of } \\
\text { freedom }\end{array}$ & $\begin{array}{l}\text { Sum of } \\
\text { squares }\end{array}$ & $\begin{array}{l}\text { Mean } \\
\text { square }\end{array}$ & F-value & $\begin{array}{c}\text { Level of } \\
\text { significance } \\
(p \leq 0.05)\end{array}$ \\
\hline Cutting direction $(\mathrm{A})$ & 1 & 1.360 & 1.360 & 0.9773 & $-^{\mathrm{ns}}$ \\
\hline Chemical type (B) & 3 & 2730.471 & 910.157 & 654.1450 & 0.0000 \\
\hline Interaction $(\mathrm{AB})$ & 3 & 172.664 & 57.555 & 41.3654 & 0.0000 \\
\hline Application repeat (C) & 3 & 186.215 & 62.072 & 44.6119 & 0.0000 \\
\hline Interaction $(\mathrm{AC})$ & 3 & 2.900 & 0.967 & 0.6947 & - --ns $^{\mathrm{n}}$ \\
\hline Interaction (BC) & 9 & 1379.078 & 153.231 & 110.1296 & 0.0000 \\
\hline Interaction (ABC) & 9 & 65.262 & 7.251 & 5.2116 & 0.0000 \\
\hline Error & 288 & 400.714 & 1.391 & & \\
\hline Total & 319 & 4938.663 & & & \\
\hline
\end{tabular}

acidic chemicals causes lightening and bleaching of the color of the wood material (Şanıvar, 2001; Sönmez, 2005). In terms of repetition number, the highest $\mathrm{L}^{*}$ value found on the untreated (control) samples (71.77), the lowest value was found on the samples one times treated with different chemicals. However, $\mathrm{L}^{*}$ value was increased both tangential (30\%) and radial (19\%) section of samples with the increase in the repetition number of the hydrogen peroxide (Table 1).

\section{Red-green color value (a*)}

ANOVA results of the red-green color $\left(a^{*}\right)$ values of samples treated with acetic acid, ammonia, hydrogen peroxide and sodium silicate at different repetition numbers were given in the Table 4 .

Table 4. ANOVA results of the $a^{*}$ values of the beech samples

According to ANOVA results, cutting direction factor and interaction of cutting direction-application repetition number factors was insignificant on the changing of a* values of beech samples. But, other factors and their reciprocal interactions was significant $(p \leq 0.05)$.
Duncan test results of the comparison in the level of cutting direction, chemical type and application repetition number were given in the Table 5.

Table 5. Duncan test results of the a* values in the level of comparison of cutting direction, chemical type and application repetition number

\begin{tabular}{|c|c|c|c|}
\hline Cutting direction & Mean & $H G$ & \multirow{3}{*}{$\begin{array}{c}L S D \\
\pm 0.2595\end{array}$} \\
\hline Tangential section & 4.92 & $\mathrm{a}$ & \\
\hline Radial sections & 5.05 & $\mathrm{a}$ & \\
\hline Chemical type & Mean & $H G$ & \\
\hline Hydrogen peroxide & 0.48 & $\mathrm{~d}$ & $L S D$ \\
\hline Acetic acid & 4.37 & $\mathrm{c}$ & \pm 0.3670 \\
\hline Ammonia & 7.11 & $\mathrm{~b}$ & \\
\hline
\end{tabular}


Table 5 (continued)

\begin{tabular}{cccc}
\hline Sodium silicate & 7.98 & $\mathrm{a}$ & \\
\hline Application repeat & Mean & $H G$ & \\
\hline Control & 4.14 & $\mathrm{c}$ & $\pm S D$ \\
1 times & 4.70 & $\mathrm{~b}$ & \pm 0.3670 \\
2 times & 4.88 & $\mathrm{~b}$ & \\
3 times & 6.22 & $\mathrm{a}$ & \\
\hline
\end{tabular}

$H G$ : Homogeneous group

According to ANOVA (Table 5) results, it was found that an insignificant interaction between $a^{*}$ values of radial and tangential section of beech wood. In terms of chemical type, the highest $a^{*}$ value $(7,98)$ found on the samples treated with sodium silicate and the lowest value $(0,48)$ was found on the samples treated with hydrogen peroxide. Hydrogen peroxide caused a significant reduction in the $\mathrm{a}^{*}$ value of beech samples. On the other hand, sodium silicate and ammonia chemicals increased $a^{*}$ values of samples (Table 1). In terms of repetition number, the highest $a^{*}$ value (6.22) found on the samples treated 3 times with chemicals and the lowest value (4.14) was found on the untreated (control) samples. The $\mathrm{a}^{*}$ values of samples generally increased with the increase of application repetition number. However, this does not include the hydrogen peroxide (Table 1).

\section{Yellow-blue color value (b*)}

ANOVA results of the yellow-blue color (b*) values of samples treated with acetic acid, ammonia, hydrogen peroxide and sodium silicate at different repetition numbers were given in the Table 6 .

Table 6. ANOVA results of the $b^{*}$ values of the beech samples

\begin{tabular}{lccccc}
\hline Factors & $\begin{array}{c}\text { Degrees of } \\
\text { freedom }\end{array}$ & $\begin{array}{c}\text { Sum of } \\
\text { squares }\end{array}$ & $\begin{array}{c}\text { Mean } \\
\text { square }\end{array}$ & F-value & $\begin{array}{c}\text { Level of } \\
\text { significance } \\
(p \leq 0.05)\end{array}$ \\
\hline Cutting direction (A) & 1 & 85.512 & 85.512 & 29.8727 & 0.0000 \\
Chemical type (B) & 3 & 2816.246 & 938.749 & 327.9425 & 0.0000 \\
Interaction (AB) & 3 & 179.438 & 59.813 & 20.8950 & 0.0000 \\
Application repeat (C) & 3 & 295.394 & 98.465 & 34.3977 & 0.0000 \\
Interaction (AC) & 3 & 83.858 & 27.953 & 9.7650 & 0.0000 \\
Interaction (BC) & 9 & 1480.233 & 164.470 & 57.4561 & 0.0000 \\
Interaction (ABC) & 9 & 177.811 & 19.757 & 6.9018 & 0.0000 \\
Error & 288 & 824.412 & 2.863 & & \\
Total & 319 & 5942.905 & & & \\
\hline
\end{tabular}

According to ANOVA results; there was a significant interaction between cutting direction, chemical type and application repetition number factors and these factors was also significant on the changes of the $b^{*}$ values of beech samples $(p \leq 0.05)$.
Duncan test results of the comparison in the level of cutting direction, chemical type and application repetition number were given in the Table 7. 
Table 7. Duncan test results of the $b^{*}$ values in the level of comparison of cutting direction, chemical type and application repetition number

\begin{tabular}{|c|c|c|c|}
\hline Cutting direction & Mean & $H G$ & \multirow{3}{*}{$\begin{array}{c}L S D \\
\pm 0.3723\end{array}$} \\
\hline Radial sections & 21.09 & $\mathrm{~b}$ & \\
\hline Tangential section & 22.12 & a & \\
\hline Chemical type & Mean & $H G$ & \multirow{5}{*}{$\begin{array}{c}L S D \\
\pm 0.5266\end{array}$} \\
\hline Hydrogen peroxide & 17.60 & $\mathrm{~d}$ & \\
\hline Ammonia & 20.73 & $\mathrm{c}$ & \\
\hline Acetic acid & 22.25 & $\mathrm{~b}$ & \\
\hline Sodium silicate & 25.84 & $\mathrm{a}$ & \\
\hline Application repeat & Mean & $H G$ & \multirow{5}{*}{$\begin{aligned} & L S D \\
\pm & 0.5266\end{aligned}$} \\
\hline Control & 20.04 & $\mathrm{c}$ & \\
\hline 2 times & 21.67 & $\mathrm{~b}$ & \\
\hline 1 times & 22.13 & $a b$ & \\
\hline 3 times & 22.58 & $\mathrm{a}$ & \\
\hline
\end{tabular}

$H G$ : Homogeneous group

According to table 7 ; the $\mathrm{b}^{*}$ value was found higher (22.12) on the tangent section when compared with the radial section. In terms of chemical type, the highest $\mathrm{b}^{*}$ value (25.84) found in the samples treated with sodium silicate and the lowest value (17.60) was found in the samples treated with hydrogen peroxide. It is found that the $b^{*}$ value of samples treated with sodium silicate was significantly higher when compared with control samples. In addition, a slight increase was observed in the $b^{*}$ values of samples (especially 3 times) treated with acetic acid and ammonia. Treatment of hydrogen peroxide led to decrease in the $\mathrm{b}^{*}$ values of the samples (Table 1). In terms of repetition number, the highest $b^{*}$ value
(22.58) found in the samples treated 3 times with chemicals and the lowest value (20.04) was found in the untreated (control) samples. The $b^{*}$ values of samples treated with sodium silicate was increased depending on the application repetition number, especially on the tangential section. It was observed that the decrease ratio of $b^{*}$ value was more in the samples treated twice with hydrogen peroxide (Table 1)

\section{Total color change $\left(\Delta \mathrm{E}^{*}\right)$}

Analysis of variance (ANOVA) results of total color change $\left(\Delta \mathrm{E}^{*}\right)$ values of samples applied with acetic acid, ammonia, hydrogen peroxide and sodium silicate at different repetition numbers were shown in Table 8 .

Table 8. ANOVA results of the $\Delta \mathrm{E}^{*}$ values of the beech samples

\begin{tabular}{lccccc}
\hline Factors & $\begin{array}{c}\text { Degrees of } \\
\text { freedom }\end{array}$ & $\begin{array}{c}\text { Sum of } \\
\text { squares }\end{array}$ & $\begin{array}{c}\text { Mean } \\
\text { square }\end{array}$ & F-value & $\begin{array}{c}\text { Level of } \\
\text { significance } \\
(p \leq 0.05)\end{array}$ \\
\hline Cutting direction (A) & 1 & 33.041 & 33.041 & 4.8250 & 0.0291 \\
Chemical type (B) & 3 & 8259.041 & 2753.014 & 402.0214 & 0.0000 \\
Interaction (AB) & 3 & 851.810 & 283.937 & 41.4631 & 0.0000 \\
Application repeat (C) & 2 & 280.568 & 140.284 & 20.4856 & 0.0000 \\
Interaction (AC) & 2 & 18.328 & 9.164 & 1.3383 & $0.2645^{\text {ns }}$ \\
Interaction (BC) & 6 & 741.154 & 123.526 & 18.0384 & 0.0000 \\
Interaction (ABC) & 6 & 234.408 & 39.068 & 5.7051 & 0.0000 \\
Error & 216 & 1479.153 & 6.848 & & \\
Total & 239 & 11897.503 & & & \\
\hline$\quad$ ns: not significant & & & & &
\end{tabular}

ns: not significant 
According to ANOVA results, it was found that an insignificant interaction between cutting direction-application repetition number factors on the changing of $\Delta \mathrm{E}^{*}$ value of beech samples $(p \leq 0.05)$. Also, it was observed that there was a significant interaction between other factors.
Duncan test results of the comparison in the level of cutting direction, chemical type and application repetition number were given in the Table 9.

Table 9. Duncan test results of the $\Delta \mathrm{E}^{*}$ values in the level of comparison of cutting direction, chemical type and application repetition number

\begin{tabular}{|c|c|c|c|}
\hline Cutting direction & Mean & $H G$ & \multirow{3}{*}{$\begin{array}{c}L S D \\
\pm 0.6659\end{array}$} \\
\hline Tangential section & 12.56 & $\mathrm{~b}$ & \\
\hline Radial sections & 13.30 & $\mathrm{a}$ & \\
\hline Chemical type & Mean & $H G$ & \multirow{5}{*}{$\begin{array}{c}L S D \\
\pm 0.9417\end{array}$} \\
\hline Acetic acid & 3.07 & $\mathrm{~d}$ & \\
\hline Ammonia & 14.40 & $\mathrm{c}$ & \\
\hline Hydrogen peroxide & 15.87 & $\mathrm{~b}$ & \\
\hline Sodium silicate & 18.37 & $\mathrm{a}$ & \\
\hline Application repeat & Mean & $H G$ & \multirow{4}{*}{$\begin{aligned} & L S D \\
\pm & 0.8155\end{aligned}$} \\
\hline 1 times & 11.46 & $\mathrm{~b}$ & \\
\hline 2 times & 13.28 & $\mathrm{a}$ & \\
\hline 3 times & 14.03 & $\mathrm{a}$ & \\
\hline
\end{tabular}

$H G$ : Homogeneous group

According to the result of comparison (Table 9); total color change value $\left(\Delta \mathrm{E}^{*}\right)$ was found higher on the radial section (13.30) than radial section. However, the total color change in both surfaces was close to each other. In terms of chemical type, the highest $\Delta \mathrm{E}^{*}$ value (18.37) was found in the samples treated with sodium silicate and the lowest value (3.07) was found in the samples treated with acetic acid. The significant increase in the $\mathrm{a}^{*}$ value and noteworthy reduction in the $\mathrm{L}^{*}$ value affected the $\Delta \mathrm{E}^{*}$ value of samples treated with sodium silicate (Table 1). In terms of application repetition number, the highest $\Delta \mathrm{E}^{*}$ value was found in the samples treated for two times (14.03) and three times (13.28) and the lowest value (11.46) was found in the samples treated for one times. The value of $\Delta \mathrm{E}^{*}$ of beech samples increased depending on the number of the repetition of the chemicals application.

\section{Conclusion}

The $L^{*}$ value of beech samples was increased in the samples treated with hydrogen peroxide and decreased in the samples treated with ammonia or sodium silicate. Acetic acid application was not caused an important change in the $\mathrm{L}^{*}$ value. The $a^{*}$ and $b^{*}$ values of samples decreased with the hydrogen peroxide application. On the other hand, sodium silicate application caused an important increase in the $\mathrm{a}^{*}$ and $\mathrm{b}^{*}$ values of samples. While acetic acid had the lowest effect on the total color change value $\left(\Delta E^{*}\right)$, sodium silicate had highest effect. In addition, the increment in the repetition number increased the $\Delta \mathrm{E}^{*}$ value of samples. It is believed that research results may be useful in achieving color matching and in reducing the effects of subsequent color changes such as protective layer application, heat, light, exposure to various chemical especially in interior applications of beech wood.

\section{Acknowledgment}

This study was presented as an oral presentation at the II. International Forestry Symposium (IFS2016), 07-10 December 2016, Kastamonu, Turkey. 


\section{References}

ASTM D2244-15a (2015). Standard practice for calculation of color tolerances and color differences from instrumentally measured color coordinates, USA.

Budakçı M., Atar, M. (2001). Effects of bleaching process on hardness and glossiness of pine wood (Pinus sylvestris L.) exposed to outdoor conditions. Turkish Journal of Agriculture and Forestry, 25(4), 201-207.

Budakçı, M., Karamanoğlu M. (2014). Effect of bleaching on hardness, gloss, and color change of weathered woods, BioResources, 9(2), 2311-2327.

Budakçı, M., Sönmez, A., Pelit, H. (2012). The color changing effect of the moisture content of wood materials on water borne varnishes. BioResources, 7(4), 54485459.

Çakıcıer, N. (1996). Ahşap yüzeylerinde kullanilan verniklerin su ile eritilen önemli ağaç boyaları ile boyanmış yüzeylerde yaptığı renk değişiklikleri. Endüstriyel Teknoloji Dergisi, 1(2), 3440.

Feirer, L. J. (1984). Furniture finishing, woodworking for industry technology and practive, pp. 834-1258, USA.

Herstedt, L., Herstedt, M. (2017). Chemical bleaching of wood: an investigation into the bleaching of mahogany, walnut, rosewood, padauk, and purpleheart. Studies in Conservation, 62(3), 162-172.

McGuire, R. G. (1992). Reporting of objective color measurements. HortScience, 27(12), 1254-1255.

Mononen, K., Alvila, L., Pakkanen, T. T. (2002). CIEL* $a^{*} b^{*}$ measurements to determine the role of felling season, log storage and kiln drying on coloration of silver birch wood. Scandinavian journal of forest research, 17(2), 179-191.

Oliver, J. R., Blakeney, A. B., Allen, H. M. (1992). Measurement of flour color in color space parameters. Cereal Chem, 69, 546-551.

Örs, Y., Atar, M. (2001). Effects of bleaching and impregnation processes on the hardness of the varnish layer in beech wood. Turkish Journal of Agriculture and Forestry, 25(6), 443-450.

Örs, Y., Keskin H. (2008). Ağaç malzeme teknolojisi. Öz Baran Ofset Matbaacılik, Ankara, Turkey.

Özçifçi, A., Atar, M., Uysal, B. (1999). The effects of wood bleaching chemicals on the surface gloss and the adhesion strength of varnishes. Turkish Journal of Agriculture and Forestry, 23(EK3), 763770.

Özdemir, T., Hiziroglu, S. (2007). Evaluation of surface quality and adhesion strength of treated solid wood. Journal of Materials Processing Technology, 186(1), 311-314.

Özdemir, T., Temiz, A., Aydın, İ. (2015). Effect of wood preservatives on surface properties of coated wood. Advances in Materials Science and Engineering, 2015, 1-6.

Sögüttü, C., Sönmez, A. (2006). Color changing effect of UV rays on some local wood species treated with various shielding agents. Gazi University Journal of the Faulty of Architecture and Engineering, 21(1), 151-159.

Sönmez, A. (1989). Durability of varnishes used on surfaces of wood furniture against important physical, mechanical, and chemical effects. Ph.D. diss., Gazi University, Institute of Science, Ankara.

Sönmez, A. (2005). Preparation and coloring, finishing on woodworking I. Gazi University, Technical Education Faculty, Ankara.

Şanıvar, N. (2001). Woodworking finishing processes, 4th edn. Milli Eğitim Basımevi, İstanbul.

TS 2470 (1976). Sampling methods and general requirements for physical and mechanical tests in wood. Turkish Standards Institution, Ankara.

TS 2471 (1976). Determination of moisture content for physical and mechanical tests in wood. Turkish Standards Institution, Ankara.

Wagner, H. W., Kiclighter, E. C. (1986). Modern woodworking. finisher and finishing. Bleaching and Disassembly, pp. 169-170, USA. 